\title{
Kalanchoe tubiflora extract inhibits cell proliferation by affecting the mitotic apparatus
}

\author{
Yi-Jen Hsieh ${ }^{1,5}$, Ming-Yeh Yang ${ }^{2}$, Yann-Lii Leu ${ }^{4}$, Chinpiao Chen ${ }^{5}$, Chin-Fung Wan ${ }^{6,7}$, Meng-Ya Chang ${ }^{3,8}$ and \\ Chih-Jui Chang ${ }^{2^{*}}$
}

\begin{abstract}
Background: Kalanchoe tubiflora (KT) is a succulent plant native to Madagascar, and is commonly used as a medicinal agent in Southern Brazil. The underlying mechanisms of tumor suppression are largely unexplored.

Methods: Cell viability and wound-healing were analyzed by MTT assay and scratch assay respectively. Cell cycle profiles were analyzed by FACS. Mitotic defects were analyzed by indirect immunofluoresence images.

Results: An n-Butanol-soluble fraction of KT (KT-NB) was able to inhibit cell proliferation. After a $48 \mathrm{~h}$ treatment with $6.75 \mu \mathrm{g} / \mathrm{ml}$ of $\mathrm{KT}$, the cell viability was less than $50 \%$ of controls, and was further reduced to less than $10 \%$ at higher concentrations. KT-NB also induced an accumulation of cells in the G2/M phase of the cell cycle as well as an increased level of cells in the subG1 phase. Instead of disrupting the microtubule network of interphase cells, KT-NB reduced cell viability by inducing multipolar spindles and defects in chromosome alignment. KT-NB inhibits cell proliferation and reduces cell viability by two mechanisms that are exclusively involved with cell division: first by inducing multipolarity; second by disrupting chromosome alignment during metaphase.

Conclusion: KT-NB reduced cell viability by exclusively affecting formation of the proper structure of the mitotic apparatus. This is the main idea of the new generation of anti-mitotic agents. All together, KT-NB has sufficient potential to warrant further investigation as a potential new anticancer agent candidate.
\end{abstract}

Keywords: Kalanchoe tubiflora, Multipolar spindle, Anti-proliferation

\section{Background}

The mitotic spindle is a complex molecular scaffold that mediates proper sister-chromatid segregation during mitosis and is essential in maintaining genomic integrity of daughter cells. In animal cells, thus far two major pathways have been identified in mitotic spindle assembly. First, the mitotic centrosomes function as microtubuleorganizing centers (MTOCs) [1], directing spindle assembly from spindle poles through the regulation of nucleating microtubules [2]. The second pathway is dependent on a RanGTP gradient mediated by Aurora A, which regulates spindle assembly $[3,4]$. The chromosomal passenger complex (CPC) generates spindle assembly in the absence of a RanGTP gradient [5,6]. Disruption of these pathways and disruption of the mitotic spindle will

\footnotetext{
* Correspondence: cjchang@mail.tcu.edu.tw

${ }^{2}$ Department of Molecular Biology and Human Genetics, Tzu Chi University, No. 701, Zhongyang Rd., Sec. 3, Hualien 97004, Taiwan

Full list of author information is available at the end of the article
}

activate the spindle assembly checkpoint, causing mitotic arrest and cell death [4].

Compounds that target microtubule assembly are often very promising as anti-cancer medication. Vinca alkaloids and taxanes, for example, are administered against both solid tumors and haematological malignancies [7-9]. Many of these compounds were originally isolated from a variety of marine organisms or botanicals [10-12]. Microtubuletargeting drugs are classified into two groups, microtubuledestabilizing agents and microtubule stabilizing agents $[13,14]$. Both microtubule -destabilizing and -stabilizing agents inhibit cell proliferation by binding to tubulin, altering microtubule dynamics, and disrupting the mitotic spindle. Cancer cells are generally more susceptible to tubulin binding agents compared to normal cells [15]. Since microtubules are present in cells that are in interphase or undergoing mitosis, these microtubule targeting agents not only disrupt mitotic spindle formation but they can also disrupt the microtubule network. The microtubule network 
mediates important cellular processes during interphase, which include cellular migration and intracellular transport. Disruption of the microtubule network can cause a diverse range cytotoxic effects [16].

Recently, a new generation of anti-mitotic agents that target kinesins and mitotic kinases, such as Eg5, Aurora kinase and polo-like kinase, were developed as putative anti-cancer medications $[17,18]$. Eg5 is a kinesin motor that localizes to the centrosomes and MT asters during prophase [19] and is required for centrosome separation as well as bipolar spindle assembly [20,21]. The aurora kinase family is crucial for the progression of cells from mitosis to cytokinesis [22-25]. Aurora A localizes to spindle poles and functions in centrosome maturation, separation and spindle bipolarity [26,27]. Aurora B is the enzymatically active member of the CPC, which localizes along the chromosome arms and at the centromeres during prophase. It is concentrated at the inner centromere region from prometaphase to metaphase and transfers to the spindle midzone, cell cortex and midbody during late mitosis and cytokinesis [25,28]. The CPC is essential both for the assembly and stability of the bipolar mitotic spindle [29]. Inhibition of Aurora B and other components of CPC causes mitotic catastrophe [29-32], indicating that CPC may be involved in both mitotic spindle assembly pathways.

Kalanchoe is a genus of the Family Crassulaceae. Various species of Kalanchoe are often referenced in folklore, and commonly used in traditional medicine worldwide for the treatment of fever, abscesses, bruises, contused wounds, coughs, skin diseases, infections, hypertension, rheumatism and inflammation [33-36]. Kalanchoe species are also used by the Kerala tribes for treating cancer symptoms [37]. A variety of bufadienolide compounds were isolated from various Kalanchoe species, which show strong anti-tumor promoting activity [38-43]. Kalanchoe tubiflora (KT), due to its wide variety of potential biological activities, was selected for this study. KT is one of the most common medicinal plants used for wound healing in Southern Brazil. The traditional uses of KT in wound healing coincide with results from systematic biological assays [44]. Here we show that an $\mathrm{n}-\mathrm{BuOH}$-soluble fraction of $\mathrm{KT}$ has antiproliferative activity, which is due to the induction of multi-polar spindles and chromosomal misalignment of mitotic cells. These abnormal mitotic events lead to mitotic catastrophe, a desirable effect of a cancer therapeutic drug.

\section{Methods}

\section{Regents}

All reagents were purchased from Sigma unless otherwise stated. The primary antibodies were used as followed: anti-alpha tubulin (mouse mAb B512, 1:2000;
Sigma, Taiwan); anti-Aurora A polyclonal antibody (1: 500, Cell signaling, Taiwan); anti-phospho-Histone 3 polyclonal antibody (1: 500, Upstate, Taiwan).

\section{Preparation of extracts from Kalanchoe tubiflora}

Fresh Kalanchoe tubiflora (KT) was chopped and boiled three times with 95\% EtOH under reflux and filtered. The filtered broth was concentrated under reduced pressure. The crude extract was resuspended in $\mathrm{H}_{2} \mathrm{O}$ and partitioned successively with $\mathrm{CHCl}_{3}$ and $n-\mathrm{BuOH}$ to give a $\mathrm{CHCl}_{3}$-soluble fraction (KT-C), a n-BuOH-soluble fraction (KT-NB), and a $\mathrm{H}_{2} \mathrm{O}$-soluble fraction (KT-W). $53.79 \mathrm{~g}$ of dry (KT-NB) extract were obtained from $6638.76 \mathrm{~g}$ of raw KT plant tissue. The procedure of KT$\mathrm{NB}$ extraction is represented in figure 1 . Stock solution was prepared in DMSO and filtered through $0.22 \mu \mathrm{m}$ membrane. Cell culture medium was used to further dilute the extracts to a desired concentration for all cellular assays.

\section{Cell lines and culture}

Human lung carcinoma (A-549), human bladder papillary transitional cell carcinoma (BFTC905), human breast carcinoma (MCF-7), human larynx Epidermoid carcinoma (HEp-2), human uterus sarcoma (MED-SA) and HeLa cells were purchased from the Food Industry Research and Development Institute (Hsinchu, Taiwan). Cells were grown, according to supplier instructions, in media supplemented with $10 \%$ fetal bovine serum (FBS). Cells were maintained at $37^{\circ} \mathrm{C}$ in a humidified atmosphere of $5 \% \mathrm{CO} 2$.

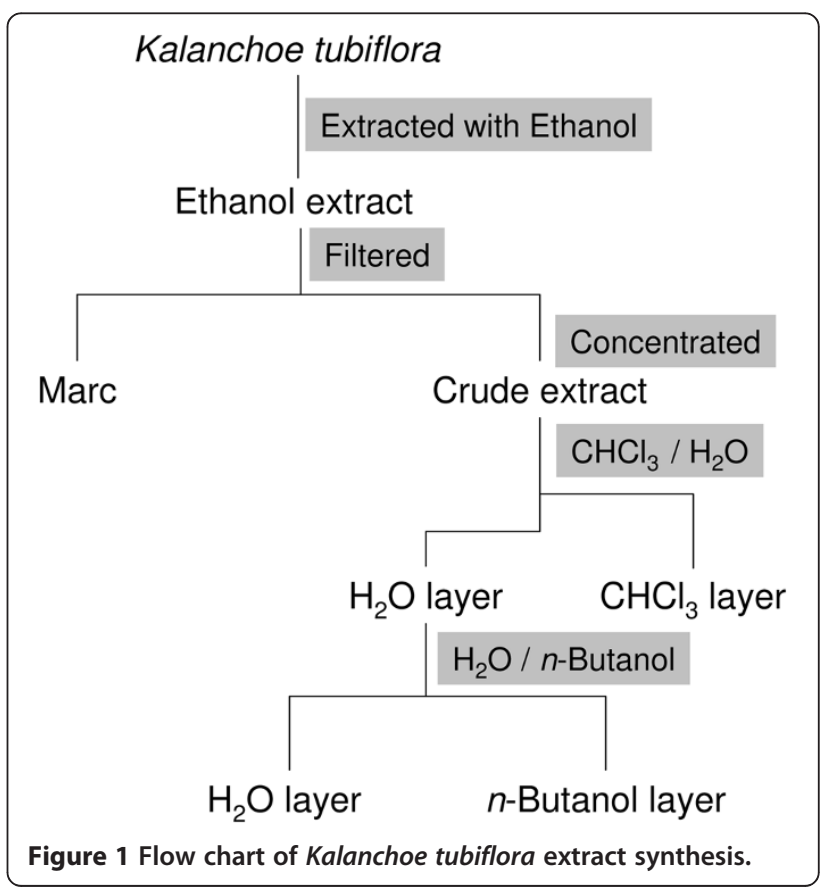




\section{Cell viability assay}

The percentage of growth inhibition was determined by the MTT cell proliferation/viability assay. A total of 2000 cells/well were seeded onto a 96-well plate for $16 \mathrm{~h}$. Cells were treated with various concentrations of KT-NB (25 $\mu \mathrm{g} / \mathrm{ml}, 12.5 \mu \mathrm{g} / \mathrm{ml}, 6.25 \mu \mathrm{g} / \mathrm{ml}, 3.125 \mu \mathrm{g} / \mathrm{ml}$, and $1.5625 \mu \mathrm{g} / \mathrm{ml}$ ) and incubated for an additional 3 days at $37^{\circ} \mathrm{C}$. The MTT assay was performed in triplicate. Subsequently, the test solutions were removed and replaced with culture medium containing $500 \mu \mathrm{g} / \mathrm{ml}$ of MTT (Thiazolyl blue formazan, Sigma, Taiwan) for an additional 4-6 h. The supernatant was aspirated, and $200 \mu \mathrm{l}$ of DMSO was added to the wells to dissolve any precipitate present. The optical density (OD) values were measured in an ELISA reader (SUNRISE, TECAN, Switzerland) at a wavelength of $570 \mathrm{~nm}$. The mean and standard deviation of each group were calculated. The OD reading of every group was first subtracted by a blank (background) control. Relative survival rate $=[\mathrm{OD}$ (treatment groups)/OD (negative control)] x 100 .

\section{Wound-healing assay}

Cell mobility was assessed using a wound-healing assay. A-549 cells were seeded in six-well plates for $24 \mathrm{~h}$. Confluent monolayer cells were scratched by a $200 \mu \mathrm{l}$ pipette tip and then removed by washing the cells with serumfree medium to clear cell debris and suspension cells. Migration of cells into the wound was observed at different time points. Cells that migrated into the wounded area or cells with extended protrusion from the border of the wound were visualized and photographed under an inverted microscope.

\section{FACS}

Cells were treated with KT-NB or DMSO and harvested at $24,48,72 \mathrm{~h}$. Floating and adherent cells were collected and fixed in cold $70 \%$ ethanol at $4{ }^{\circ} \mathrm{C}$ overnight. After washing, cells were treated with RNase and stained with Propidium Iodide (PI) for $1 \mathrm{~h}$ in the dark at room temperature. Flow cytometric analysis was performed by using a FACScalibur flow cytometer (Becton Dickinson). Cell cycle distribution was analyzed using Cell Quest software (Becton Dickinson). Each experiment was conducted three times.

\section{Immunofluorescence and microscopy}

For immunostaining, cells were fixed in $4 \%$ paraformaldehyde in PBS buffer for $10 \mathrm{~min}$ at room temperature. The cells were permeabilized in $0.1 \%$ Triton X-100 in PBS for $5 \mathrm{~min}$ and then rinsed in PBS. Cells were blocked for $30 \mathrm{~min}$ at room temperature in PBS $+10 \%$ FBS. Antibody incubations were performed in PBS for $1 \mathrm{~h}$, followed by four 10-min washes in PBS at room temperature. DNA was stained with $0.1 \mathrm{mg} / \mathrm{ml}$ DAPI for $5 \mathrm{~min}$ at room temperature and rinsed with PBS. Slides were mounted in Vectashield mounting medium (Vectra) and sealed using nail varnish.

Images were performed using a Zeiss Axiovert $200 \mathrm{M}$ microscope controlled by MetaMorph Software. Image stacks were deconvolved and quick-projected. The images were processed using Adobe Photoshop.

\section{Results}

\section{KT-NB decreases cell viability}

We treated HeLa cells with different doses of KT-NB to analyze its effect of cell proliferation. Cells were exposed to three different concentrations of KT-NB and DMSO, which was used as a control. At each time point, the cell number was determined using a haemocytometer. Compared to control cells, $1.35 \mu \mathrm{g} / \mathrm{ml}$ of KT-NB only slightly affected cell growth; however, cell growth was inhibited at concentrations of $6.75 \mu \mathrm{g} / \mathrm{ml}$ and $13.5 \mu \mathrm{g} / \mathrm{ml}$ after a $48 \mathrm{~h}$ treatment (Figure 2A). We also used the MTT assays to assess the anti-proliferative effect of KT-NB on Hep2, MES-SA, BFTC905, MCF7, HeLa and A549 cells (Figure 2B). These cells were treated with KT-NB

\section{A}

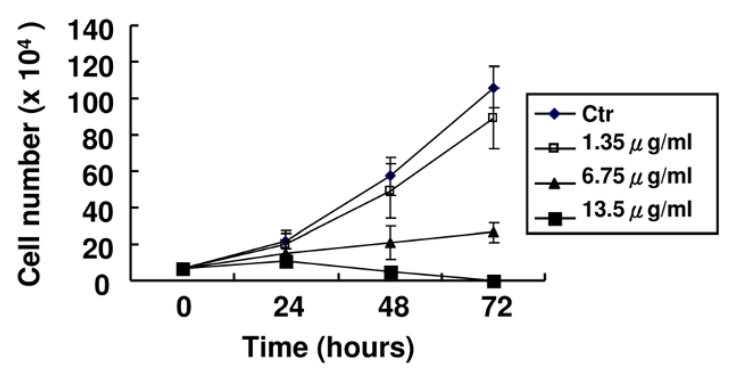

B

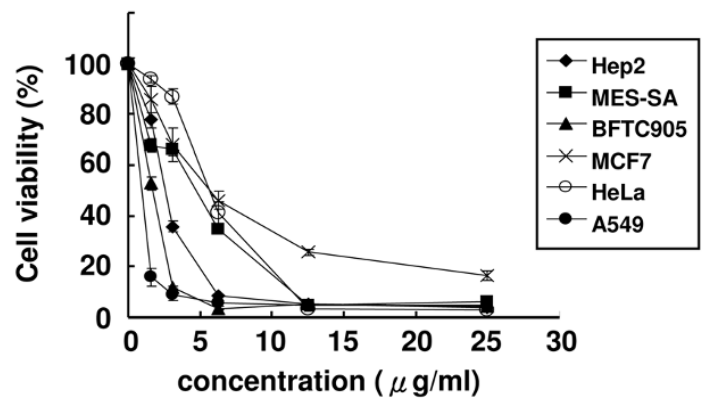

Figure 2 KT-NB inhibits cell proliferation and reduces cell viability. (A) HeLa cells were treated with different concentration of KT-NB $(1.35 \mu \mathrm{g} / \mathrm{ml}, 6.75 \mu \mathrm{g} / \mathrm{ml}, 13.5 \mu \mathrm{g} / \mathrm{ml})$. DMSO was used as control. Cell numbers were determined using a haemocytometer at different time points. (B) Human lung carcinoma (A-549), human bladder papillary transitional cell carcinoma (BFTC905), human breast carcinoma (MCF-7), human larynx Epidermoid carcinoma (HEp-2), human uterus sarcoma (MED-SA) and HeLa cells were treated with $1.5625 \mu \mathrm{g} / \mathrm{ml}, 3.125 \mu \mathrm{g} / \mathrm{ml}, 6.25 \mu \mathrm{g} / \mathrm{ml}, 12.5 \mu \mathrm{g} / \mathrm{ml}, 25 \mu \mathrm{g} / \mathrm{ml}$ of KT-NB for $72 \mathrm{~h}$ and harvested for MTT assay. Results were based on three independent experiments. 
$(1.5625 \mu \mathrm{g} / \mathrm{ml}, 3.125 \mu \mathrm{g} / \mathrm{ml}, 6.25 \mu \mathrm{g} / \mathrm{ml}, 12.5 \mu \mathrm{g} / \mathrm{ml}$, and $25 \mu \mathrm{g} / \mathrm{ml}$ ) for $72 \mathrm{~h}$ and harvested for analysis. KT-NB reduced the viability of the different cancer cells in a dose dependant manner. The IC50 of KT-NB in A549 cells was less than $1.5625 \mu \mathrm{g} / \mathrm{ml}$. KT-NB could also inhibit the growth of other cancer cells at slightly higher concentrations $(6.25 \mu \mathrm{g} / \mathrm{ml})$. Compared to cancer cells, the toxicity of KT-NB was less in normal cells (Additional file 1: Figure S1). It is worthy of note that there was ambiguity whether the reduced cell growth rate resulted from cell death or non-proliferating. Overall, these results showed that KT-NB could effectively inhibit the growth of cancer cells at concentrations less than $6.25 \mu \mathrm{g} / \mathrm{ml}$.

\section{KT-NB inhibits cell migration}

A wound healing assay was performed to assess the effect of KT-NB on A549 cell migration. In response to a scratch wound, cells treated with KT-NB (3 $\mu \mathrm{g} / \mathrm{ml}$, $12.5 \mu \mathrm{g} / \mathrm{ml}$, and $50 \mu \mathrm{g} / \mathrm{ml}$ ) exhibited a concentration and time dependent decrease in cell migration. Cell migration was slightly inhibited at lower KT-NB concentrations $(3 \mu \mathrm{g} / \mathrm{ml})$, while at the concentration of $50 \mu \mathrm{g} / \mathrm{ml}$, KT-NB almost completely blocked the migration of cells into the scratch wound (Figure 3). Note that this inhibition effect might due to either inhibition of cell migration or induction of cell death after KT-NB treatment.

\section{KT-NB induces cell cycle arrest}

FACS analysis was performed to examine the effect of KT-NB on the cell cycle. After $24 \mathrm{~h}$ treatment of KT$\mathrm{NB}$, a progressive accumulation of cells were found in the G2/M phase of the cell cycle, which was accompanied with a decrease of cells in the G1 phase (Figure 4A). The mitotic index in control and KT-NB treated cells was examined by both anti-phospho-Histone H3 staining and DAPI staining under a fluorescence microscope. The mitotic index increased from $8 \%$ in control cells to $20 \%$ in cells treated with $6.75 \mu \mathrm{g} / \mathrm{ml}$ of KT-NB at $24 \mathrm{~h}$ (Figure 4B). We also observed that cells exposed to $\mathrm{KT}$ exhibited higher levels of subG1 with DNA content less than $2 \mathrm{~N}$. The level of cells in the subG1 phase increased to $35 \%$ after $72 \mathrm{~h}$ treatment (Figure $4 \mathrm{C}$ ).

\section{KT-NB induces multipolar spindles}

Since KT-NB treatment induces cell cycle arrest during mitosis, we analyzed whether KT-NB could cause mitotic spindle defects and regulate important mitotic checkpoints. To analyze the structure of mitotic
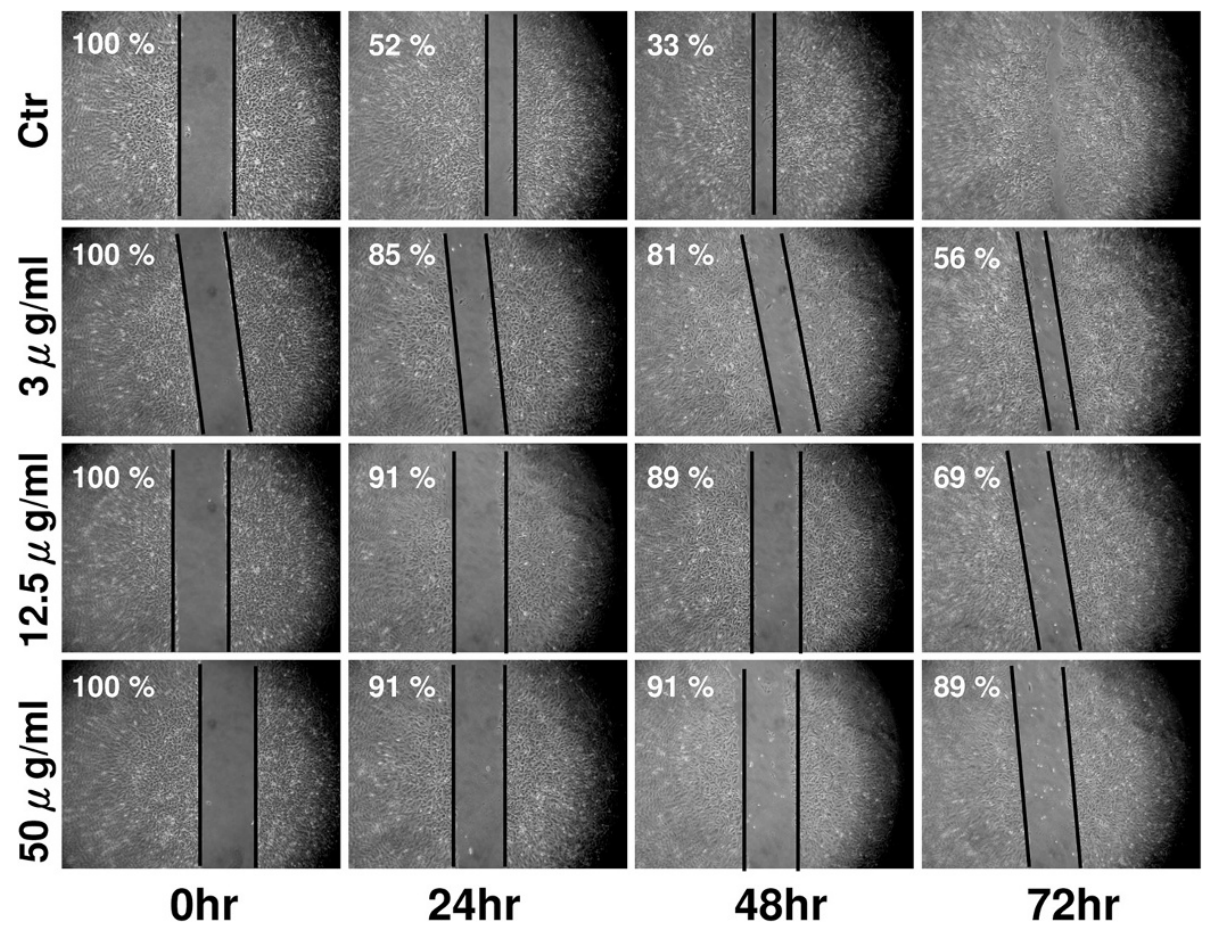

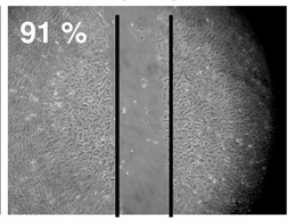

48hr

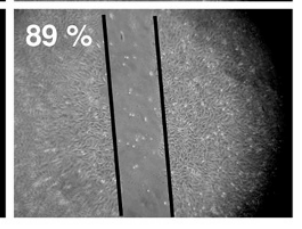

$72 \mathrm{hr}$

Figure 3 KT-NB inhibits cell migration in a wound healing assay. A-549 cells were seeded in six-well plates and allowed to adhere for $24 \mathrm{~h}$. Cells were treated with $3 \mu \mathrm{g} / \mathrm{ml}, 12.5 \mu \mathrm{g} / \mathrm{ml}, 50 \mu \mathrm{g} / \mathrm{ml}$ of KT-NB. Migration of cells into the wound was observed at $24,48,72 \mathrm{~h}$ after monolayer cells were scratched by a $200 \mu \mathrm{l}$ pipette tip. Results are based on three independent experiments. Lines indicated the border of the wounds. Imagines were processed using Photoshop software. The contrast of the images was adjusted to that the border could be identified without ambiguity. The border lines were determined by eyes. 


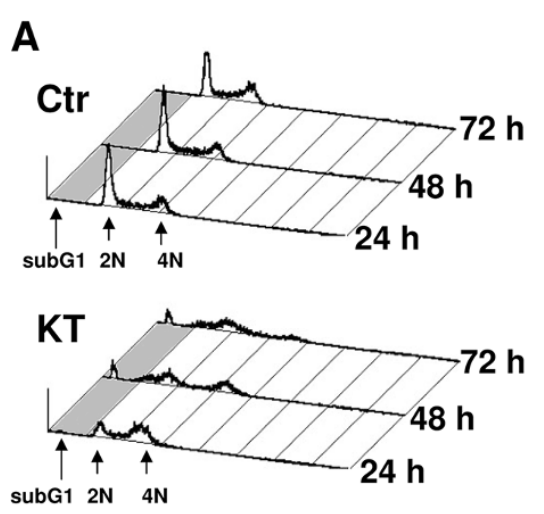

\begin{tabular}{|c|c|c|c|}
\hline & $24 \mathrm{~h}$ & $48 \mathrm{~h}$ & $72 \mathrm{~h}$ \\
\hline subG1 & $0.1 \%$ & $0.2 \%$ & $0.3 \%$ \\
\hline G1 & $53 \%$ & $53 \%$ & $54 \%$ \\
\hline S & $25 \%$ & $28 \%$ & $28 \%$ \\
\hline \multirow[t]{2}{*}{ G2/M } & $16 \%$ & $14 \%$ & $15 \%$ \\
\hline & $24 \mathrm{~h}$ & $48 \mathrm{~h}$ & $72 \mathrm{~h}$ \\
\hline subG1 & $7 \%$ & $26 \%$ & $33 \%$ \\
\hline G1 & $37 \%$ & $15 \%$ & $19 \%$ \\
\hline S & $17 \%$ & $16 \%$ & $10 \%$ \\
\hline G2/M & $33 \%$ & $14 \%$ & $11 \%$ \\
\hline
\end{tabular}
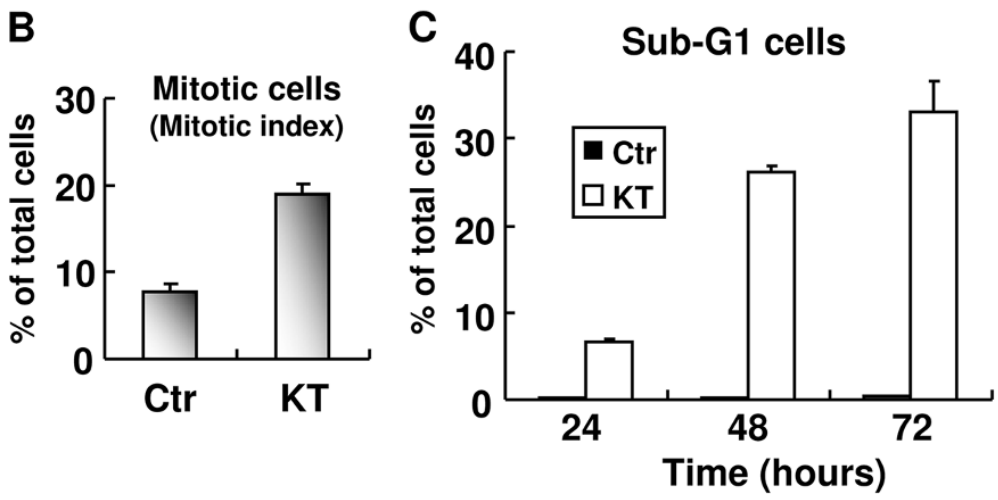

Figure 4 KT-NB arrests cells in the M phase and increases sub-G1 cell population. (A) FACS analysis of DNA content after KT-NB treatment. HeLa cells were treated with $6.75 \mu \mathrm{g} / \mathrm{ml}$ of KT-NB or DMSO as control. Cells were harvested for analysis after 24, 48 and $72-\mathrm{h}$ treatment. Tables showed the percentage of relative cell numbers of different cell cycle phases. (B) Cells were treated with $6.75 \mu \mathrm{g} / \mathrm{ml} \mathrm{KT}$-NB for $24 \mathrm{~h}$. Quantitation of the mitotic index in control and KT-NB treated cells ( $n>500$, three independent experiments). (C) Percentage of relative cell numbers of sub-G1 cells. Cells were calculated based on the results shown in (A).

spindles, we used HeLa cells to performed immunofluorescent staining. The mitotic phases of cells were carefully analyzed by DAPI and microtubule staining. Majority of the control cells showed perfect bipolar structure during metaphase (Figure 5A). In contrast, cells treated with $6.75 \mu \mathrm{g} / \mathrm{ml}$ of KT-NB for $24 \mathrm{~h}$ exhibited multipolar spindles (Figures 5B, 6A and 6B). More than half of the mitotic cells had more than two spindle poles (Figure 5C). To examine whether KT-NB treatment can alter important components involved in the mitotic spindle poles, the localization of Aurora A was analyzed. Cells treated with KT-NB showed normal Aurora A localization to spindle poles (Figure 6A).

Aurora $B$ is required for stability of the bipolar mitotic spindle [32] and functions through the phosphorylation of histone $\mathrm{H} 3$ on Ser10 and Ser28 in prophase. Our results indicated that KT-NB treated cells also did not exhibit altered levels of Histone $\mathrm{H} 3$ phosphorylation (Figure 6B). Immunofluorescence analysis of $\alpha$-tubulin and $\gamma$-tubulin revealed that the microtubule organization and centrosome number were normal in cells treated with KT-NB in interphase (data not shown). Taken together, these results suggested that KT-NB treatment induced multipolar spindles but did not interfere with the recruitment of essential components necessary for functional spindle poles, nor did it disrupt the microtubule network in interphase cells.

\section{KT-NB induces chromosome misalignment in metaphase}

KT-NB treatment induced a large amount of mitotic cells with multipolar spindles, but $45 \%$ of the mitotic cells still showed normal bipolar spindles. Unexpectedly, KT-NBtreated cells with normal bipolar spindle assembly experienced problems in the chromosomal congression to the metaphase plate (Figures $7 \mathrm{~B}$ and $7 \mathrm{C}$ ). To specify this phenotype, we only analyzed metaphase cells. In cells treated with KT-NB for $24 \mathrm{~h}, 37 \%$ of the metaphase cells with bipolar spindles contained misaligned chromosomes (Figure 7D). In contrast, control cells in metaphase exhibited correct chromosomal alignment at the metaphase plate (Figure 7A). It is worthy to note that high percentage of mitotic cells with mitotic apparatus defects was observed if all phases of mitotic cells were analyzed. By grouping cells that exhibited misaligned chromosomes with bipolar spindles or that exhibited multipolar spindles (i.e. abnormal mitotic cells), the level of defective mitotic 

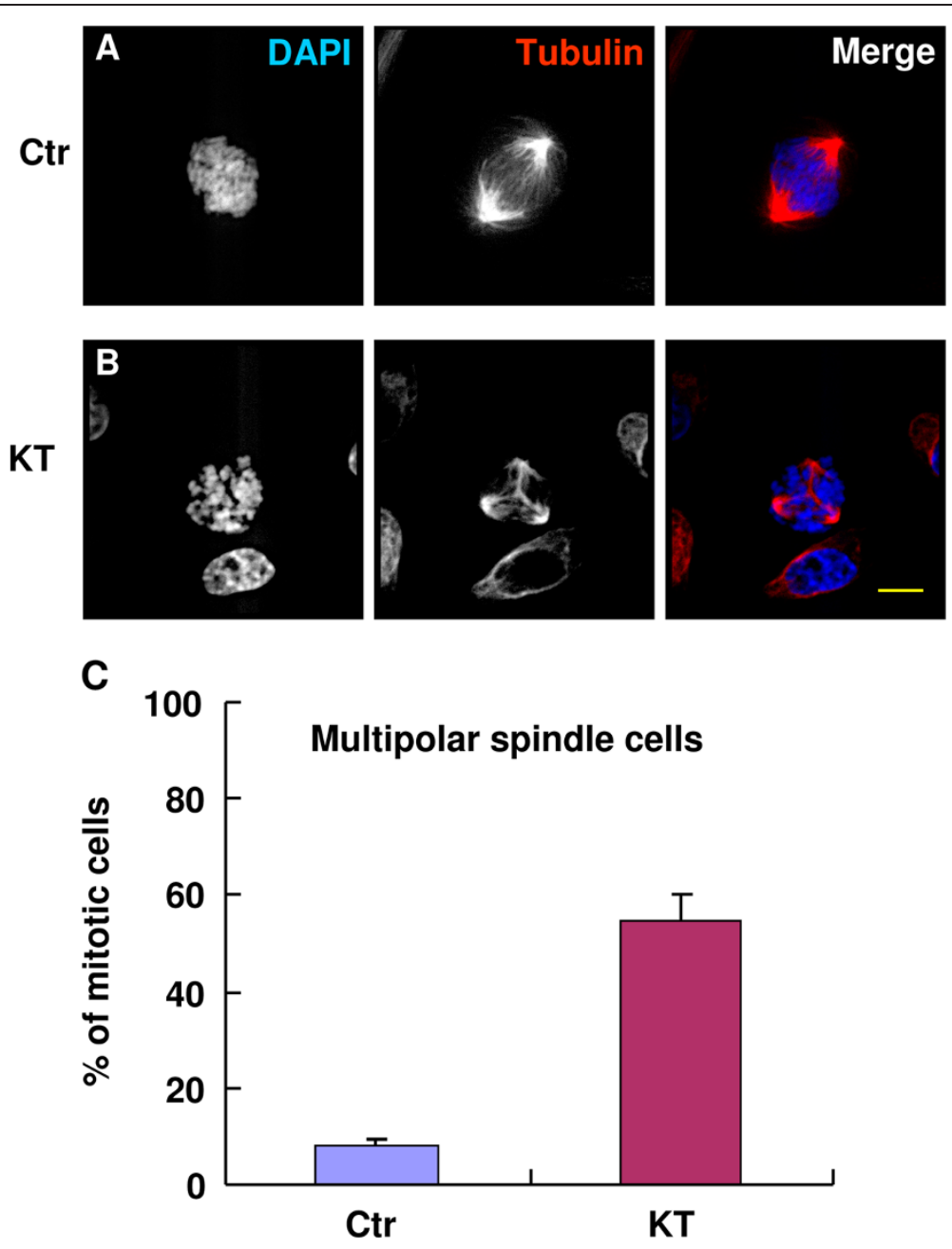

Figure 5 KT-NB induces multipolar spindles. HeLa cells were treated with DMSO as a control (A) or $6.75 \mu \mathrm{g} / \mathrm{ml}$ of KT-NB (B) for 24 h. After incubation, cells were fixed and processed for immunofluorescence analysis. DAPI was used for DNA staining, while anti-tubulin shows the mitotic spindle. Merged images: (DAPI is blue, tubulin is red). (C) The percentage of mitotic cells with multipolar spindles was quantified in control and KT-NB treated cells ( $n>100$, three independent experiments). Scale bar: $5 \mu \mathrm{m}$.
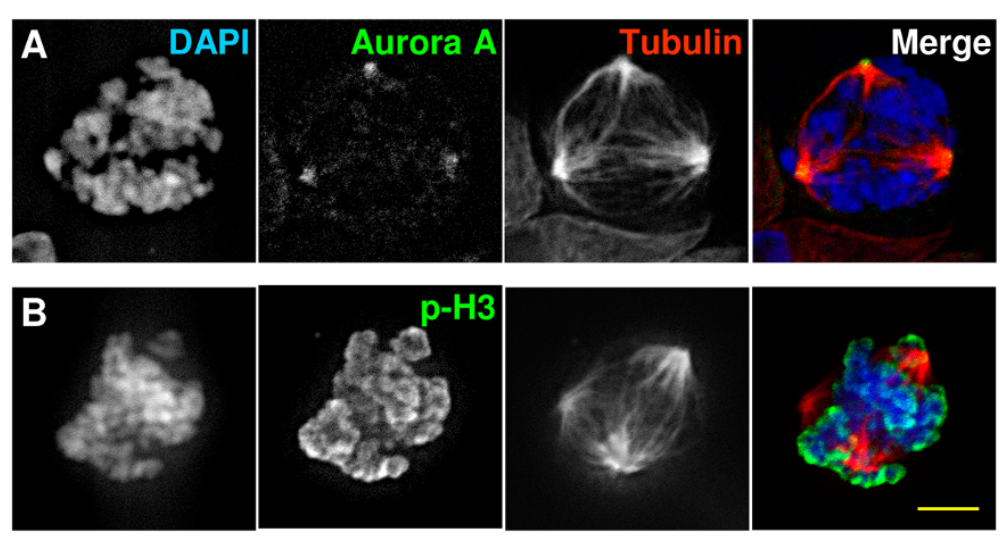

Figure 6 KT-NB does not affect Aurora A localization and histone H3 phosphorylation on serine ${ }^{10}$. HeLa cells were treated with $6.75 \mu \mathrm{g} / \mathrm{ml}$ of KT-NB for $24 \mathrm{~h}$ and harvested for immunofluorescence analysis. DAPI was used for DNA staining, while anti-tubulin shows the mitotic spindle. Cells were immunostained with. anti-Aurora A (A) or Anti-phospho-histone H3 (Ser10) (B). Merged images DAPI is blue, anti-tubulin is red, Aurora A $(\mathbf{A})$ or histone $\mathrm{H3}(\mathbf{B})$ is green. Scale bar: $5 \mu \mathrm{m}$. 

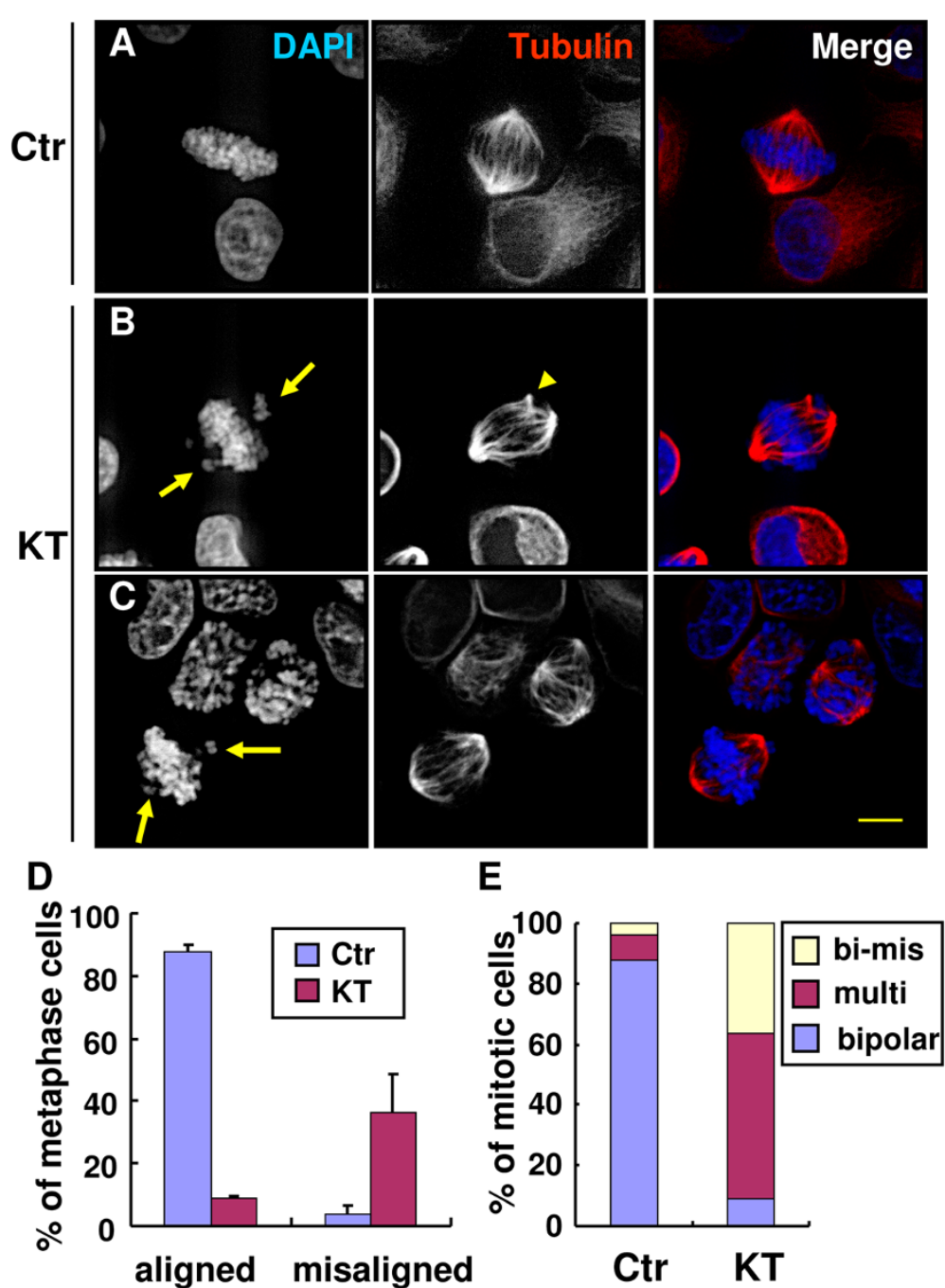

E

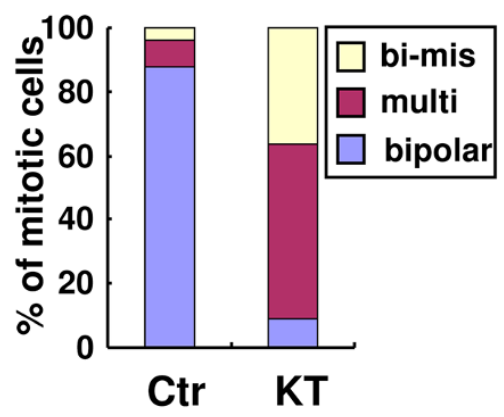

Figure 7 KT-NB induces chromosomal misalignment in cells with bipolar spindles. Cells were treated with DMSO as control (A) or $6.75 \mu \mathrm{g} /$ $\mathrm{ml}$ of KT-NB (B, C) for $24 \mathrm{~h}$. After incubation, cells were fixed and processed for immunofluorescence analysis. (A) The control cell in metaphase showed bipolar spindle with chromosome alignment to the metaphase plate. (B) The KT-NB treated cell showed bipolar spindle containing extra centrosome (arrowhead). (C) The KT-NB treated cells exhibited bipolar spindle with the normal two centrosomes. Arrows points to the misalignment chromosomes. DAPI was used for DNA staining, while anti-tubulin shows the mitotic spindle. Merged images: (DAPI is blue, tubulin is red). Scale bar: $5 \mu \mathrm{m}$. (D) Only the metaphase cells were analyzed. The percentage of metaphase cells with misaligned chromosome(s) in the bipolar spindle were quantified in control and KT-NB treated cells ( $n>50$, three independent experiments). (E) All phases of mitotic cells were analyzed. The percentage of mitotic cells with multipolar spindles or misaligned chromosome(s) was quantified in control and KT-NB treated cells ( $n>100$, three independent experiments). Bi-mis: cells with bipolar spindle and misaligned chromosomes. Multi: cells with multipolar spindles.

cells after KT-NB treatment was, at 90\%, much higher than control cells (Figure 7E).

\section{Discussion}

Medicinal plants are an important source for the potential development of effective anticancer agents [45]. In fact, more than half of the today's anticancer drugs were originally synthesized from natural products and their derivatives. In the present study, we found that extracts from Kalanchoe tubiflora (KT), exhibited significant anti-proliferative effects against a variety of human cancer cell lines.
Majority of the effective anti-cancer or antibiotic concentrations of plant extracts are greater than $100 \mu \mathrm{g} / \mathrm{ml}$ $[45,46]$; however, in our study, cell proliferation was inhibited by $48 \mathrm{~h}$ treatment with $6.75 \mu \mathrm{g} / \mathrm{ml} \mathrm{KT-NB}$, and the viability was less than $50 \%$ after a $72 \mathrm{~h}$ exposure. KT-NB does affect normal diploid human cells that are dividing but much less efficiently than most of the cancerous cell lines we tested. Therefore, KT-NB may be a highly effective candidate as a future anti-cancer drug.

Drugs based on natural products that bind to tubulin or microtubules remain an important component in chemotherapy. Anti-mitotic agents inhibit cell proliferation by 
suppressing microtubule dynamics [13]; however, based on immunofluorescence staining images, we found that KT-NB did not disrupt the microtubule organization in interphase or spindle formation during mitosis, indicating that it is not a microtubule destabilizing agent. [47]. Our results also showed that KT-NB, which did not lead to the formation of parallel microtubule alignment or packed bundles of microtubules, is not a microtubule stabilizing agent either [48]. Rather than acting on microtubule dynamics, we found that KT-NB induces multipolar spindles and perturbs accurate mitosis.

Centrosomes increase both in size and in microtubulecapacity in late G2 phase of the cell cycle. Aurora A, by recruiting pericentriolar material (PCM) and interacting with the Ran-TPX2 pathway, is required for the maturation of centrosomes and mitotic-spindle assembly respectively $[3,49]$. It was noted that depletion of TPX2 from Xenopus egg extracts results in the formation of less compact spindles [50]. In vertebrate cells, depletion of TPX2 using RNAi also caused the formation of multipolar spindles [51]; however, inhibition of Aurora A activity results in monopolar spindles [24]. Our immunostaining results showed that localization of Aurora A was not disrupted by KT-NB. Since we did not observe a high level monopolar spindles, an effect common with Aurora A inhibitors, it is also unlikely that KT-NB inhibits Aurora A activity.

Some of the KT-NB-treated cells showed normal bipolar spindles with two centrosomes in mitosis. It was noted that a few cells with more than two centrosomes could assemble almost bipolar spindles (Figure 7B). With KT-NB treatment, it did not matter whether spindles were formed by the normal two centrosomes or by extra centrosomes, as more than half of the cells with bipolar spindles failed to exhibit properly aligned chromosomes at the metaphase plate. Although, chromosomal misalignment can result from the suppression of microtubule dynamics by a stabilizing poison, such as taxol [48], as discussed previously, this is an unlikely mechanism for KT-NB.

The failure of non-bipolar attachment corrections during the stochastic attachment process in prometaphase, is another possibility for chromosomal misalignment. Aurora B, the enzymatic member of CPC, destabilizes the non-bipolar microtubule-kinetochore attachments by phosphorylating several microtubule capture factors on the kinetochore [52-54]. To examine if the misaligned chromosome in KT-NB treatment was due to the inhibition of Aurora B kinase, we analyzed the histone $\mathrm{H} 3$ phosphorylation levels. In prophase, the CPC localizes to the chromosome arms where it phosphorylates histone H3 on Ser10 and Ser28 [25]. Phosphorylation of histone $\mathrm{H} 3$ was not affected in KT-NB treated cells (Figure 6B).
Plk is a central regulator of the cell cycle, playing crucial roles in mitotic events, including activation of CDC25c phosphatase, regulation of microtubule nucleation, centrosome maturation and kinetochore assembly $[55,56]$. To ensure the accuracy of these processes, plk1 activity is subjected to complex regulation. It is activated at mitotic entry by Aurora A kinase and its adapator BORA, which phosphorylate plk1 in its T-loop [57,58]. Plk1 is also activated by Aurora B kinase at centromeres, and that is ccrucial for polo function in regulating chromosome dynamics in prometaphase [59]. In our study, monopolar spindles were not observed in KT-NB treated cells. Two other possible targets of KT-NB are CENP-E and Mps1. CENP-E is a plus end-directed motor protein that has a pivotal role in mitosis. It stabilizes the interaction between microtubules and kinetochores of the mitotic spindle [60] and regulates the mitotic checkpoints by modulating the function of BuBR1 [61]. Complete inhibition of CENP-E leads to defective mitosis with unaligned chromosomes and apoptosis [62]. Mps1 was originally discovered in a yeast genetic screen for mutants producing monopolar spindle [63]. It is a conserved multi-functional kinase that plays roles in the SAC and chromosome bi-orientation [64]. Some small-molecular inhibitors of Mps1 were developed in 2010 [65]. Chemical inhibition of Mps1 leads to chromosome misalignment and increases the frequency of multipolar mitoses [66].

David Pellman's group used live cell images to study the fate of cells with extra centrosomes in 2009 [67]. According to their study, most of progeny of multipolar cells died or arrested regardless of whether the cells were mono- or poly-nucleated. It will be interesting to use live cell images in the future to reveal the fate of KT-NB treated cells.

Targeting of mitotic cells is one of the bases of therapy for patients with multiple types of solid tumors. Some antimitotic agents, taxanes or vinca alkaloids, affect both dividing and nondividing cells. An essential characteristic of the ideal new generation of antimitotic agents is to target dividing cells but not non-dividing cells. As most cancer cells have faster dividing rates, these drugs target cancer cells preferentially. Potentially then, perturbing the mitotic apparatus by KT-NB may be used to more efficiently target rapidly proliferating cancer cells.

\section{Conclusions}

Here we report that KT-NB is a promising anti-cancer agent candidate. Further in vivo research will be needed to determine the effectiveness of KT-NB as an actual anti-cancer compound. Unlike microtubule binding agents, KT-NB inhibits cell proliferation and reduces cell viability by two mechanisms: first, by inducing multipolarity; second, by disrupting chromosome alignment 
during metaphase. Both mechanisms disrupt mitotic progression and inhibiting cell proliferation. The underlying mechanism of KT-NB is complicated and unclear. Further research involving the identification and isolation of pure compounds that parallel the phenotypes observed in KT-NB treated cells will be necessary to determine the cellular targets of KT-NB.

\section{Additional file}

Additional file 1: Figure S1. The toxicity of KT-NB was less in normal cells. (A) Normal female embryonic lung cells (WI-38) and lung cancer cells (A549) were treated with different concentrations of KT-NB (1.35 $\mu \mathrm{g} / \mathrm{ml}, 6.75 \mu \mathrm{g} / \mathrm{ml}, 13.5 \mu \mathrm{g} / \mathrm{ml}$ and $25 \mu \mathrm{g} / \mathrm{ml})$. DMSO was used as a control. Cells were harvested for MTT assay at different time points. The absorbance of the control group was defined as 100\%. Results were based on three independent experiments. (B) Cell morphology of WI-38 was unaffected after KT-NB treatment for $72 \mathrm{~h}$.

\section{Competing interests}

The authors declare that there are no conflicts of interest.

\section{Authors' contributions}

YJH carried out extraction, wound healing assay, data analysis. MYY carried out immunostaining, MTT assay. YLL collected plant and identified Kalanchoe tubiflora. CPC and CFW participated in extraction design. MYC carried out microscopy. CJC conceived of the study, and participated in its design and coordination and helped to draft the manuscript. All authors read and approved the final manuscript.

\section{Acknowledgments}

We like to thank Mar Carmena and Ji-Hshiung Chen for their critical reading of the manuscript. We also thank Tang K. Tang for providing image systems. Work in CJC's laboratory was funded by the National Science Council, Taiwan.

\section{Author details}

'Department of Laboratory Medicine and Biotechnology, Tzu Chi University, Hualien 97004, Taiwan. ${ }^{2}$ Department of Molecular Biology and Human Genetics, Tzu Chi University, No. 701, Zhongyang Rd., Sec. 3, Hualien 97004, Taiwan. Institute of Medical Sciences, Tzu Chi University, Hualien, Taiwan. ${ }^{4}$ Graduate Institute of Natural Products, Chang Gung University, Taoyuan, Taiwan. ${ }^{5}$ Department of Chemistry, National Dong-Hwa University, Hualien, Taiwan. ${ }^{6}$ School of Applied Chemistry, Chung Shan Medical University, No.110,Sec.1, Jianguo N.Road, Taichung City 40201, Taiwan. ${ }^{7}$ Institute of NanoEngineering and MicroSystems, National Tsing Hua University, No. 101, Section 2, Kuang-Fu Road, Hsinchu 30013, Taiwan. ${ }^{8}$ Department of Medical Research, Buddhist Tzu-Chi General Hospital, Hualien, Taiwan.

Received: 26 March 2012 Accepted: 31 August 2012

Published: 10 September 2012

\section{References}

1. Bettencourt-Dias M, Glover DM: Centrosome biogenesis and function: centrosomics brings new understanding. Nat Rev Mol Cell Biol 2007, 8:451-463.

2. O'Connell $\mathrm{CB}$, Khodjakov AL: Cooperative mechanisms of mitotic spindle formation. J Cell Sci 2007, 120:1717-1722.

3. Tsai MY, Wiese C, Cao K, Martin O, Donovan P, Ruderman J, Prigent C, Zheng Y: A ran signalling pathway mediated by the mitotic kinase Aurora A in spindle assembly. Nat Cell Biol 2003, 5:242-248.

4. Rieder CL, Maiato H: Stuck in division or passing through: what happens when cells cannot satisfy the spindle assembly checkpoint. Dev Cell 2004, 7:637-651

5. Sampath SC, Ohi R, Leismann O, Salic A, Pozniakovski A, Funabiki H: The chromosomal passenger complex is required for chromatin-induced microtubule stabilization and spindle assembly. Cell 2004, 118:187-202.
6. Maresca TJ, Salmon ED: Intrakinetochore stretch is associated with changes in kinetochore phosphorylation and spindle assembly checkpoint activity. J Cell Biol 2009, 184:373-381.

7. Pajk B, Cufer T, Canney P, Ellis P, Cameron D, Blot E, Vermorken J, Coleman R, Marreaud S, Bogaerts J, et al: Anti-tumor activity of capecitabine and vinorelbine in patients with anthracycline- and taxane-pretreated metastatic breast cancer: findings from the EORTC 10001 randomized phase II trial. Breast 2008, 17:180-185.

8. Norris B, Pritchard KI, James K, Myles J, Bennett K, Marlin S, Skillings J, Findlay B, Vandenberg T, Goss P, et al: Phase III comparative study of vinorelbine combined with doxorubicin versus doxorubicin alone in disseminated metastatic/recurrent breast cancer: national cancer institute of Canada clinical trials group study MA8. J Clin Oncol 2000, 18:2385-2394.

9. Dimitroulis J, Stathopoulos GP: Evolution of non-small cell lung cancer chemotherapy (Review). Oncol Rep 2005, 13:923-930.

10. Amador ML, Jimeno J, Paz-Ares L, Cortes-Funes H, Hidalgo M: Progress in the development and acquisition of anticancer agents from marine sources. Ann Oncol 2003, 14:1607-1615.

11. Schiff PB, Fant J, Horwitz SB: Promotion of microtubule assembly in vitro by taxol. Nature 1979, 277:665-667.

12. Wani MC, Taylor HL, Wall ME, Coggon P, McPhail AT: Plant antitumor agents. VI. The isolation and structure of taxol, a novel antileukemic and antitumor agent from taxus brevifolia. J Am Chem Soc 1971, 93:2325-2327.

13. Dumontet C, Jordan MA: Microtubule-binding agents: a dynamic field of cancer therapeutics. Nat Rev Drug Discov 2010, 9:790-803.

14. Kavallaris M: Microtubules and resistance to tubulin-binding agents. Nat Rev Cancer 2010, 10:194-204.

15. Brito DA, Rieder CL: The ability to survive mitosis in the presence of microtubule poisons differs significantly between human nontransformed (RPE-1) and cancer (U2OS, HeLa) cells. Cell Motil Cytoskeleton 2009, 66:437-447.

16. Canta A, Chiorazzi A, Cavaletti G: Tubulin: a target for antineoplastic drugs into the cancer cells but also in the peripheral nervous system. Curr Med Chem 2009, 16:1315-1324.

17. Sudakin $\mathrm{V}$, Yen TJ: Targeting mitosis for anti-cancer therapy. BioDrugs 2007, 21:225-233.

18. Taylor S, Peters JM: Polo and Aurora kinases: lessons derived from chemical biology. Curr Opin Cell Biol 2008, 20:77-84.

19. Sawin KE, Mitchison TJ: Mutations in the kinesin-like protein Eg5 disrupting localization to the mitotic spindle. Proc Natl Acad Sci USA 1995, 92:4289-4293.

20. Tanenbaum ME, Macurek L, Galjart N, Medema RH: Dynein, Lis1 and CLIP170 counteract eg5-dependent centrosome separation during bipolar spindle assembly. EMBO J 2008, 27:3235-3245.

21. Tanenbaum ME, Macurek L, Janssen A, Geers EF, Alvarez-Fernandez M, Medema RH: Kif15 cooperates with eg5 to promote bipolar spindle assembly. Curr Biol 2009, 19:1703-1711.

22. Carmena M, Earnshaw WC: The cellular geography of aurora kinases. Nat Rev Mol Cell Biol 2003, 4:842-854.

23. Carmena M, Ruchaud S, Earnshaw WC: Making the Auroras glow: regulation of Aurora $A$ and $B$ kinase function by interacting proteins. Curr Opin Cell Biol 2009, 21:796-805.

24. Marumoto T, Honda S, Hara T, Nitta M, Hirota T, Kohmura E, Saya H: AuroraA kinase maintains the fidelity of early and late mitotic events in HeLa cells. J Biol Chem 2003, 278:51786-51795.

25. Ruchaud S, Carmena M, Earnshaw WC: Chromosomal passengers: conducting cell division. Nat Rev Mol Cell Biol 2007, 8:798-812.

26. Barr AR, Gergely F: Aurora-A: the maker and breaker of spindle poles. J Cell Sci 2007, 120:2987-2996.

27. Vader G, Lens SM: The Aurora kinase family in cell division and cancer. Biochim Biophys Acta 2008, 1786:60-72.

28. Vader G, Maia AF, Lens SM: The chromosomal passenger complex and the spindle assembly checkpoint: kinetochore-microtubule error correction and beyond. Cell Div 2008, 3:10.

29. Gassmann R, Carvalho A, Henzing AJ, Ruchaud S, Hudson DF, Honda R, Nigg EA, Gerloff DL, Earnshaw WC: Borealin: a novel chromosomal passenger required for stability of the bipolar mitotic spindle. J Cell Biol 2004, 166:179-191.

30. Dar AA, Goff LW, Majid S, Berlin J, El-Rifai W: Aurora kinase inhibitors-rising stars in cancer therapeutics? Mol Cancer Ther 2010, 9:268-278. 
31. Ryan BM, O'Donovan N, Duffy MJ: Survivin: a new target for anti-cancer therapy. Cancer Treat Rev 2009, 35:553-562.

32. Adams RR, Maiato H, Earnshaw WC, Carmena M: Essential roles of Drosophila inner centromere protein (INCENP) and aurora B in histone $\mathrm{H} 3$ phosphorylation, metaphase chromosome alignment, kinetochore disjunction, and chromosome segregation. J Cell Biol 2001, 153:865-880

33. Heyne K, The Useful Indonesian Plants: Research and Development Agency. Jakarta: Ministry of Forestry; 1987:845-846.

34. Sjamsu Hidayat SS, Hutapea JR: Indonesian Medicinal Plants (I): Research and Development Agency. Jakarta: Ministry of Health; 1991:220-221.

35. Supratman U, Fujita T, Akiyama K, Hayashi H: Insecticidal compounds from Kalanchoe daigremontiana $x$ tubiflora. Phytochemistry 2001, 58:311-314.

36. Lans CA: Ethnomedicines used in Trinidad and Tobago for urinary problems and diabetes mellitus. J Ethnobiol Ethnomed 2006, 2:45.

37. Mathew PJ, Unnithan CM: Search for plants having anti-cancer properties used by the tribals of Wynadu, Mallappuram and Palghat districts of Kerala. India Aryavaidyan 1992, 6:54-60.

38. Lai ZR, Ho YL, Huang SC, Huang TH, Lai SC, Tsai JC, Wang CY, Huang GJ, Chang YS: Antioxidant, anti-inflammatory and antiproliferative activities of Kalanchoe gracilis (L.) DC stem. Am J Chin Med 2011, 39:1275-1290.

39. Yamagishi T, Haruna M, Yan XZ, Chang JJ, Lee KH: Antitumor agents, 110. Bryophyllin B, a novel potent cytotoxic bufadienolide from Bryophyllum pinnatum. J Nat Prod 1989, 52:1071-1079.

40. Costa SS, Jossang A, Bodo B, Souza ML, Moraes VL: Patuletin acetylrhamnosides from Kalanchoe brasiliensis as inhibitors of human lymphocyte proliferative activity. J Nat Prod 1994, 57:1503-1510.

41. Wu PL, Hsu YL, Wu TS, Bastow KF, Lee KH: Kalanchosides A-C, new cytotoxic bufadienolides from the aerial parts of Kalanchoe gracilis. Org Lett 2006, 8:5207-5210.

42. Kuo P, Kuo T, Su C, Liou M, Wu T: Cytotoxic principles and a-pyrone ringopening derivatives of bufadienolides from Kalanchoe hybrida. Tetrahedron 2008, 64:3392-3396.

43. Supratman U, Fujita T, Akiyama K, Hayashi H, Murakami A, Sakai H, Koshimizu K, Ohigashi H: Anti-tumor promoting activity of bufadienolides from Kalanchoe pinnata and K. daigremontiana $\mathrm{x}$ tubiflora. Biosci Biotechnol Biochem 2001, 65:947-949.

44. Schmidt C, Fronza M, Goettert M, Geller F, Luik S, Flores EM, Bittencourt CF, Zanetti GD, Heinzmann BM, Laufer S, Merfort I: Biological studies on Brazilian plants used in wound healing. J Ethnopharmacol 2009, 122:523-532.

45. Cragg GM, Newman DJ: Plants as a source of anti-cancer agents. J Ethnopharmacol 2005, 100:72-79.

46. Tang YQ, Jaganath IB, Sekaran SD: Phyllanthus spp. induces selective growth inhibition of PC-3 and MeWo human cancer cells through modulation of cell cycle and induction of apoptosis. PLoS One 2010, 5 e12644.

47. Ganguly A, Yang H, Cabral F: Paclitaxel-dependent cell lines reveal a novel drug activity. Mol Cancer Ther 2010, 9:2914-2923.

48. Jordan MA, Toso RJ, Thrower D, Wilson L: Mechanism of mitotic block and inhibition of cell proliferation by taxol at low concentrations. Proc Natl Acad Sci USA 1993, 90:9552-9556.

49. Mori D, Yano Y, Toyo-oka K, Yoshida N, Yamada M, Muramatsu M, Zhang D, Saya H, Toyoshima YY, Kinoshita K, et al: NDEL1 phosphorylation by Aurora-A kinase is essential for centrosomal maturation, separation, and TACC3 recruitment. Mol Cell Biol 2007, 27:352-367.

50. Wittmann T, Wilm M, Karsenti E, Vernos I: TPX2, a novel xenopus MAP involved in spindle pole organization. J Cell Biol 2000, 149:1405-1418.

51. Garrett S, Auer K, Compton DA, Kapoor TM: HTPX2 is required for normal spindle morphology and centrosome integrity during vertebrate cell division. Curr Biol 2002, 12:2055-2059.

52. Biggins S, Murray AW: The budding yeast protein kinase Ipl1/Aurora allows the absence of tension to activate the spindle checkpoint. Genes Dev 2001, 15:3118-3129.

53. Lampson MA, Renduchitala K, Khodjakov A, Kapoor TM: Correcting improper chromosome-spindle attachments during cell division. Nat Cell Biol 2004, 6:232-237.

54. Cheeseman IM, Chappie JS, Wilson-Kubalek EM, Desai A: The conserved KMN network constitutes the core microtubule-binding site of the kinetochore. Cell 2006, 127:983-997.

55. Petronczki $M$, Lenart $P$, Peters JM: Polo on the rise-from mitotic entry to cytokinesis with Plk1. Dev Cell 2008, 14:646-659.
56. Archambault V, Glover DM: Polo-like kinases: conservation and divergence in their functions and regulation. Nat Rev Mol Cell Biol 2009, 10:265-275.

57. Macurek L, Lindqvist A, Lim D, Lampson MA, Klompmaker R, Freire R, Clouin C, Taylor SS, Yaffe MB, Medema RH: Polo-like kinase- 1 is activated by aurora A to promote checkpoint recovery. Nature 2008, 455:119-123.

58. Seki A, Coppinger JA, Jang CY, Yates JR, Fang G: Bora and the kinase Aurora a cooperatively activate the kinase Plk1 and control mitotic entry. Science 2008, 320:1655-1658

59. Carmena M, Pinson X, Platani M, Salloum Z, Xu Z, Clark A, Macisaac F, Ogawa H, Eggert U, Glover DM, et al: The chromosomal passenger complex activates polo kinase at centromeres. PLOS Biol 2012, 10: e1001250.

60. McEwen BF, Chan GK, Zubrowski B, Savoian MS, Sauer MT, Yen TJ: CENP-E is essential for reliable bioriented spindle attachment, but chromosome alignment can be achieved via redundant mechanisms in mammalian cells. Mol Biol Cell 2001, 12:2776-2789.

61. Mao Y, Abrieu A, Cleveland DW: Activating and silencing the mitotic checkpoint through CENP-E-dependent activation/inactivation of BubR1. Cell 2003, 114:87-98

62. Wood KW, Lad L, Luo L, Qian X, Knight SD, Nevins N, Brejc K, Sutton D, Gilmartin $A G$, Chua PR, et al: Antitumor activity of an allosteric inhibitor of centromereassociated protein-E. Proc Natl Acad Sci USA 2010, 107:5839-5844.

63. Winey M, Goetsch L, Baum P, Byers B: MPS1 and MPS2: novel yeast genes defining distinct steps of spindle pole body duplication. J Cell Biol 1991, 114:745-754.

64. Abrieu A, Magnaghi-Jaulin L, Kahana JA, Peter M, Castro A, Vigneron S, Lorca T, Cleveland DW, Labbe JC: Mps1 is a kinetochore-associated kinase essential for the vertebrate mitotic checkpoint. Cell 2001, 106:83-93.

65. Lan W, Cleveland DW: A chemical tool box defines mitotic and interphase roles for Mps1 kinase. J Cell Biol 2010, 190:21-24.

66. Kwiatkowski N, Jelluma N, Filippakopoulos P, Soundararajan M, Manak MS, Kwon M, Choi HG, Sim T, Deveraux QL, Rottmann S, et al: Small-molecule kinase inhibitors provide insight into Mps1 cell cycle function. Nat Chem Biol 2010, 6:359-368.

67. Ganem NJ, Godinho SA, Pellman D: A mechanism linking extra centrosomes to chromosomal instability. Nature 2009, 460:278-282.

doi:10.1186/1472-6882-12-149

Cite this article as: Hsieh et al:: Kalanchoe tubiflora extract inhibits cell proliferation by affecting the mitotic apparatus. BMC Complementary and Alternative Medicine 2012 12:149.

\section{Submit your next manuscript to BioMed Central and take full advantage of:}

- Convenient online submission

- Thorough peer review

- No space constraints or color figure charges

- Immediate publication on acceptance

- Inclusion in PubMed, CAS, Scopus and Google Scholar

- Research which is freely available for redistribution 